\title{
DESCRIPTIONS OF FIVE NEW SPECIES OF FISHES SRNT BY PROF. A. DUGÈS FROM THE PROVINCE OF GUANAJUATO, MEXICO.
}

\section{Ry TARLETON H. B EAN, Curator, Department of Fishes, U. S. National Priseum.}

(With one plate.)

It is probable that the species described in this paper are from streams belonging to the Pacific slope of the Province of Guanajuato; the Lampetra certainly is, and it is the most southerly representative of the genus recorded. A recent examination of the types of Goodea atripinnis Jordan, proves the existence of villiform teeth behind the incisors, and throws Goodea into the synonymy of Characodon.

\section{Characodon variatus, n. sp. (Pl. XX, f. 1.)}

This species resembles $C$. lateralis Gthr., from which it differs chiefly in its larger number of dorsal rays, and in the more advanced position of the dorsal fin, as well as in the size of the ventral.

The types are numbered 37809 .

In form the species resembles C. lateralis as figured in Trans. Zool. Soc., Lond., VI, 1869, pl. LXXXII, fig. 2. The head is broad and depressed; the nape moderately arched. The snout is short; the lower jaw strongly projecting; the jaws are much heavier than in C. atripinnis (Goodea atripinnis Jordan), and the villiform teeth behind the incisors are much more developed than in $C$. atripinnis. The caudal peduncle (that is, the distance from the end of the dorsal to the origin of the caudal) is nearly as long as the head, equaling one-fourth of the total length without the caudal.

There are about thirteen or fourteen bicuspid teeth in the outer series of the upper jaw and from sixteen to eighteen in the lower jaw. The band of villiform teeth behind the incisors is fully developed in both jaws. The mandible does not extend back to the anterior margin of the orbit; its length is about equal to that of the orbit. The jaws are moderately protractile. The mandible when the mouth is closed is almost vertically placed. The snout is shorter than the eye whose diameter is two-sevenths of the length of the head and about two-thirds of the width of the interorbital space. The interorbital space is as long as the opercle and one-half the length of the head without the snout.

Scales on the top of the head little enlarged. Opercle united by membrane to the shoulder girdle, beginning slightly above the upper edge of the pectoral. The insertion of the dorsal is about midway between the end of the scales and the hind margin of the orbit. The first dorsal ray is very slender, articulated, and about two-thirds as long as the second; the second is simple like the first, and is shorter than the third; 
the fifth ray is the longest, its length, in the female, equaling that of the postorbital part of the head. In the male the dorsal rays are somewhat longer. The base of the dorsal is equal in length to the postorbital part of the head, and is one-half the greatest height of the body.

The anal is inserted under the seventh or eighth ray of the dorsal. Its longest ray is about two-fifths the length of the head.

The pectoral is inserted below the middle of the body, its upper edge being on a level with the lower border of the orbit; its length is contained five and a third to six times in total to base of candal.

The ventral is inserted midway between the tip of the snout and the end of the scales.

The caudal is truncate, with the external rays slightly rounded.

The head is one-fourth of the total length, including caudal, and equals depth of body at the dorsal origin.

D. $13-14$; A. 15-16; scales 15-35.

Coloration in spirits.-Olive brown above, lighter below; the opercle silvery, overlaid below with orange; the abdomen with a yellowish tinge; lips dusky; iris pale; scales of upper half of body dusky at base; lower half of body with numerous dark spots, the largest about as long as the pupil.

\section{Characocion bilineatus, n. sp. (Pl. XX, f. 2.)}

The type of this species is a sin le example, number 37832, measuring $1 \frac{7}{10}$ inches in length. It resembles the preceding species, number 37809 , but has a smaller eye and greater number of dorsal rays, larger scales and different coloration.

In form the species resembles $C$. lateralis Gthr. The head is broad and depressed, the interorbital space being nearly flat, and the nape is moderately arched. The snout is short, rather shorter than the eye, and the lower jaw is somewhat prominent. The jaws are stout, as in C. lateralis. The upper jaw is moderately protractile. There are about 20 bicuspid teeth in the outer series of the lower jaw, and about as many in the upper jaw. The villiform teeth behind the incisors can readily be made out. The mandible is nearly vertical when the month is closed; it does not nearly reach to below the eye. Its length is about equal to that of the eye, which is one-fourth as long as the head, and scarcely more than one-half the width of the interorbital space.

The scales on the top of the head are somewhat enlarged. The opercle is connected by membrane to the shoulder girdle, beginning at a point slightly above the upper edge of the pectoral.

The insertion of the dorsal is midway between the posterior margin of the eye and the end of the scales. The first dorsal ray is slender, articulated, and shorter than the second. The longest dorsal ray is about two-thirds as long as the head. The base of the dorsal is equal in length to the head without the snout, and is contained fire times in the total without caudal. 
The anal is inserted under the third ray of the dorsal. Its longest ray is as long as the postorbital part of the head.

The pectoral is inserted very slightly below the middle of the body, its upper edge being nearly on a level with the lower edge of the orbit. Its length is one-fifth of the total length without the caudal.

The caudal is truncate, its length contained four or four and one-half times in the standard length.

The length of the head is contained three and two-thirds times in the total without caudal, and is much less than the depth at the dorsal origin.

The length of the caudal peduncle equals that of the head. The least height of the caudal peduncle is a little more than one-half the greatest height of the body, which is rather more than one-third of the length without caudal.

The ventral reaches about to the vent; its length is nearly one-half that of the head.

D. 16 ; A. 16 ; seales $11-32$.

Coloration in spirits.--Upper parts brown; lighter below, probably orange in life; the operculum silvery; a purple stripe along the mid. dle of the body, its greatest width about equal to the length of the eye; abdomen silvery, this color extending up to the purple stripe; a purplish stripe on the edge of the candal peduncle, from the end of the anal to the caudal. Iris, golden.

Characodon ferrugineus, n. sp. (Pl. XX, f. 3 ô, f. 4 q ).

The types of the present description are a male and female (No. 37810). The male is $2 \frac{7}{10}$ inches long and the female 2 inches.

This species is very readily distinguished from the two precelling by its much larger eye as well as its coloration. The male is very deep bodied and much compressed in its posterior half. The interorbital space is nearly tlat and the arch of the nape is very gradual. The height at the pectoral origin is as great as at the dorsal origin and equals the length of the head, which is one-third of the total, without the caudal. The snout is short, skorter than the eye, and less than one-fourth the length of the head. The lower jaw is obliquely placed and somewhat projecting; its length equals that of the eye, which is two-sevenths of the length of the head. The upper jaw is moderately protractile. The bicuspid teeth of the lower jaw are about twenty in number, and behind them is a series of well-developed villiform teeth. The teeth of the upper jaw are similar to those of the lower. The jaws are moderately stout. The mandible scarcely reaches to below the front margin of the orbit. Its length is about three-fourths that of the interorbital space, which is one-half of the length of the head without the snout. The scales on the top of the head are somewhat enlarged. The opercle is connected by membrane to the shoulder girdle, beginning at a point slightly above the upper edge of the pectoral. The insertion of the dorsal is about midway between the posterior margin of the eye and the end of the 
scales. The first dorsal ray is slender, articulated, and somewhat more than one-half as long as the second, which is about three-fourths as long as the third. The longest ray of the dorsal is two-thirds as long as the head. The base of the dorsal is one-sixth as long as the total without caudal. The anal is inserted under the fifth ray of the dorsal. Several of the anterior rays of the anal are modified, being shorter than the rest and crowded together. The longest anal ray is nearly one-half as long as the head.

The pectoral is inserted considerably below the middle of the depth of the body, its upper edge being on a level with the lower margin of the orbit; its length is one-fifth of the total without the caudal.

The caudal is imperfect, and its exact shape cannot be determined.

The length of the head is contained $3 \frac{1}{3}$ times in the total, without candal, and is less than the greatest depth of the body. The length of the caudal peduncle equals that of the head without the snout; the least height of the caudal peduncle equals one-half the length of the head.

The ventral is inserted at about the middle of the total length without the caudal and it reaches to the vent; its length is about two-fifths of the length of the head.

D. 13 ; A. $15-16$; scales $14-35$.

Coloration in spirits. - The male is chestnut brown, with an indistinct dark lateral stripe made up of a series of interrupted dark blotches. Opercle silvery; abdomen yellowish.

The female is without the lateral stripe, the whole side being covered with irregular brown blotches. The opercle is silvery and the belly yellowish.

Fundulus dugèsii, n. sp. (Pl. XX, f. 5).

The types of the following description are two females (No. 37831), one of which is $60^{\mathrm{mm}}$ and the other $64^{\mathrm{mm}}$ in length. Besides these large females there are numerous additional examples of both sexes, the smallest being a male $37^{\mathrm{mm}}$ in length. The total number of examples of this species is eleven. The exact locality is not known; they were sent with other species from Guanajuato, Mexico, by Prof. A. Dugès.

This new species of Fundulus differs greatly from all the other species known from the vicinity in having a very short anal base. In Fundulus labialis, punctatus, guatemalensis, and pachycephalus the bases of the dorsal and anal fins are nearly equal in length, but in this species the anal base is one-half as long as the dorsal base. The species about to be described resembles $F$. guatemalensis and $F$. pachycephalus in the shape of the body. The largest example, however, has a more decided elevation at the nape than any of the others. The head is moderately broad with the interorbital space depressed and flat, and its length is nearly one-third of the total without the caudal, and is about equal to the height of the body. In the smaller of the typical specimens the nape is scarcely arched. The snout is short, shorter than the eye, and 
the lower jaw projects slightly. The jaws are short and moderately stout, the upper jaw being freely protractile. The length of the upper jaw is slightly more than one-third the length of the head, and equal to the length of the mandible. The teeth are slender, conical, in a double series, of which the outer is enlarged. The mandible reaches to the vertical through the front of the eye; its position is oblique when the mouth is closed; its length is slightly more than one-third the length of the head and less than the width of the interorbital space. The eye is one-fourth as long as the head and only two-thirds of the width of the interorbital space.

The opercle is connected by membrane to the shoulder girdle, beginning at a point about in the line of the lower margin of the eye. The insertion of the dorsal is very slightly in advance of the insertion of the anal and at a distance from the front of the eye equaling about twice the length of the head. Its rays are slender and not very long, the longest being somewhat shorter than the base of the fin and less than one-half the length of the head. The base of the dorsal equals one-half the length of the head. The anal is inserted about under the third ray of the dorsal; its longest ray is one-third to two-fifths as long as the head. The anal base is very short, one-half as long as the dorsal base and very little longer than the eye.

The pectoral is inserted considerably below the middle of the body, about at the beginning of its lower third, its upper edge being below the level of the lower edge of the orbit; its length is one-half that of the head.

The caudal is slightly rounded, its middle rays being one-fifth as long as the total without the caudal. The least height of the caudal peduncle is one-half the greatest height of the body. The distance from the end of the dorsal to the origin of the middle caudal rays is slightly more than the least height of the eaudal peduncle.

The ventral is situated nearly in the middle of the total length, excluding the caudal; it does not reach the vent; its length is about onethird of the head's length.

D. 15 ; A. 11; Scales 11-30.

Coloration in spirits.-General color light brown; the sides with five or six dusky bands, the widest somewhat greater than the length of the eye; one of these bands is placed under the anterior half of the dorsal. On the sides and head the green color is intermingled with silver. Anterior half of abdomen with a yellowish tinge. Cheeks bronze in the upper portion, silvery below. Operculum silvery.

\section{Lampetra spadicea, n. sp. (Pl. XX, f. 6).}

The U. S. National Museum has had in its possession for several years a larval lamprey received from Guanajuato, Mexico, and recently Prof. A. Dugès, from whom the earlier specimens came, has sent an adult example. The specimen which forms the type of this description is $7 \frac{2}{5}$ inches long. Its catalogue number is 38005 . 
This Lampetra resembles L. plumbea Ayres, but plumbea has the mandibulary plate with eight cusps instead of nine; and instead of the four bicuspid lateral teeth plumbea has three, the median one distinctly tricuspid. In our best developed specimen of plumbea also, the lingual teeth are pectinate, but the number of pectinations is comparatively smaller than in the Mexican species, and the middle of the series is furnished with a conical lobe which is very greatly enlarged. This may be a character of youth.

Nostril on the top of the head and rery slightly in front of the eye.

The head is somewhat longer than the chest, its length contained $7 \frac{1}{3}$ times in the total. The mouth is moderately large; the lips with a conspicuous fringe of papillæ. The dorsal fin is inserted about midway of the total length. It is separated into two portions by an interspace which is one-half as long as the snout. The greatest height of the anterior portion is about equal to the length of the eye, which is about one-fourth of the length of the snout. The second dorsal is longer than the first, but very little higher, its greatest height being about one-third of the length of the snout. In its posterior portion there is a deep notch, but no separation from the portion which is continued around the tail. The eye is rather small, about one-fourth as long as the snout and stightly more than one-half of the width of the interorbital space. The maxillary tooth has large cusps which are well separated; no trace of a median cusp. The mandibular plate is curved and has nine teeth, those at the extremities being somewhat enlarged. Four lateral bicuspid teeth. Numerous small, recurved teeth around the margin of the disk, in many rows anteriorly, but reduced to two rows, well separated, posteriorly. The lingual teeth are distinctly pectinate; twenty lobes may be counted with a glass.

The general color is chestnut brown, somewhat lighter on the belly. Basal portion of the second dorsal pale; the remaining portion somewhat like the body. 


\section{$2 \mathrm{BHL}$ Biodiversity Heritage Library}

Bean, Tarleton H. 1887. "Descriptions of five new species of fishes sent by Prof. A. Dugès from the Province of Guanajuato, Mexico." Proceedings of the United States National Museum 10(637), 370-375. https://doi.org/10.5479/si.00963801.10-637.370.

View This Item Online: https://www.biodiversitylibrary.org/item/32314

DOI: https://doi.org/10.5479/si.00963801.10-637.370

Permalink: https://www.biodiversitylibrary.org/partpdf/23733

\section{Holding Institution}

Smithsonian Libraries

\section{Sponsored by}

Smithsonian

\section{Copyright \& Reuse}

Copyright Status: NOT_IN_COPYRIGHT

This document was created from content at the Biodiversity Heritage Library, the world's largest open access digital library for biodiversity literature and archives. Visit BHL at https://www.biodiversitylibrary.org. 